\title{
SHORT-PERIOD EVOLUTION IN EU LEGAL TEXTS: OLD AND NEW TERMS, OLD AND NEW CONCEPTS
}

\section{INTRODUCTION}

Terminological variation in specialised-domain texts has been of increasing interest in recent years, challenging the approach adopted in the early days of Terminology which encouraged the avoidance of synonymy or any other linguistic factor considered as possible causes of ambiguous communication. The progressive acknowledgment of changes in terminology has led to a growing number of studies tackling the phenomenon of variation and evolution from different perspectives. Terminological variation has been mainly studied by taking into account either the vertical axis, i.e. considering variation as the result of different registers, or the horizontal axis and, on that account, considering one register only and observing the change in terms in relation to different expressive purposes or preferences of the authors. However, in the last two decades more attention has been paid also to a third axis, the temporal axis, which implies that the changes in terminology can be attributed to the evolution of the knowledge domain it refers to.

Given that these three axes are not mutually exclusive, the main focus in this paper, which concentrates on the terminology used in documents published by the institutions of the European Union (EU) on the criminal law domain of victims of crime, is the diachronic aspect of terminological variation. It should be noted that the peculiarities of the texts analysed make it possible to hold the variables of the other two axes constant. On the one hand, the register of all the selected documents can be considered almost homogeneous, since all of them are texts with or without legal force dealing with specialised topics within the broad area of victims of crime and their rights. On the other hand, the selected documents have different communication purposes, with, for instance, directives imposing obligations on Member States, green papers stimulating debate and favouring a consultation process and judgments resolving causes that derive mainly from doubts or delays in the interpretation of EU law. However, also on the horizontal axis it can be said that they are rather homogeneous, given that they are all produced by the EU institutions and they fall within the broad aim of developing and enforcing EU law. The purpose of this article is to illustrate the variation and evolution phenomena that can be observed in such documents in English and Italian and to analyse them from a diachronic perspective taking into account a short period of time (1998-2012).

Author's address: Department of Legal, Language, Translation and Interpreting Studies, University of Trieste, Via Filzi 14, 34132 Trieste, Italy. E-mail: kperuzzo@units.it 


\section{TERMINOLOGICAL VARIATION AND THE GENERAL THEORY OF TERMINOLOGY}

Ever since the first studies in Terminology in the 1930s, the existence of diverse terms to refer to a single concept - nowadays referred to as "terminological variation" (see, for instance, Ibekwe-SanJuan 1998; Freixa 2002; Kerremans 2010) - has been recognised as a linguistic phenomenon characterising both general and specialised language. However, the approach adopted by early terminologists to deal with this phenomenon was considerably different from those developed mainly in the last two decades. The aim of the approach developed by Wüster (1979) and his colleagues was achieving unambiguous communication among experts. Therefore, Wüster's conviction in the need for the systematisation and standardisation of specialised lexical units and his fight against synonymy have led to the elaboration of both international principles which were to be generally applied in practical terminographic tasks and more general, abstract principles. These have in turn given birth to what is known as the "General Theory of Terminology" (GTT).

The GTT principles are task-oriented: they can only be applied when the aim is to standardise a domain-specific terminology to achieve unambiguous communication. Therefore, the terminographic tasks carried out following the GTT approach are prescriptive in their nature. However, the strict viewpoint proposed by early GTT supporters has been modulated by admitting controlled synonymy, complementing the study of terminological units with that of phraseology, considering spoken as well as written forms, and introducing the description of term formation and the representation of conceptual structures which are not necessarily ordered hierarchically (see Cabré 2003: 167-168).

\section{THE INCLUSION OF TERMINOLOGICAL VARIATION IN TEXTUAL TERMINOLOGY}

According to the GTT, a term and the relevant concept are linked via a bi-univocal relation, which means that one term only can designate a concept (monosemy) and one concept can only be denoted by one term (mononymy). However, the application of specialised corpora to terminological studies since the early 1990s has led to the questioning of the ideal of bi-univocity between terms and concepts and the recognition of polysemy as a linguistic phenomenon characterising also language for special purposes (LSP) (see, for instance, Zawada/Swanepoel 1994; Condamines/ Rebeyrolle 1997; Eriksen 2002; Ferrari 2002). The bi-univocity postulate has thus been extensively criticised by alternative paradigms, among which Socioterminology (Gaudin 1993, 2003), the Communicative Theory of Terminology (Cabré 1999) and Sociocognitive Terminology (Temmerman 2000) are particularly worth mentioning.

The main alternative approaches to the GTT share some common features. Among all, they are descriptive, rely on empirical evidence provided by text and corpus analysis and follow a mainly semasiological line, occasionally complemented by some onomasiological contributions. What indeed needs to be highlighted is that they all acknowledge two fundamental aspects. Firstly, they recognise LSPs as a form of natural 
language subject to variation due to several factors (e.g. topic, intended aim, genre, target audience, etc.). Since terminological units share the same features that are generally attributed to lexical units in the general language and "[a]ny process of communication involves variation of lexical forms, which manifest themselves as alternative denominations for the same concept (synonymy) or in the semantic openness of one form (polysemy)" (Cabré 2000: 49-50), it follows that variation also concerns terminology. Secondly, they all consider the underlying concept systems as being everchanging rather than static, hence denying the stability of designations over time and leaving room for the study of terminology from a diachronic perspective. Therefore, the more recently developed descriptive approaches admit and sometimes encourage polysemy and synonymy, since they are considered as functional elements in LSP discourse (Temmerman/Kerremans 2003: 2). These approaches have brought about an almost complete reversal in the study of terminology, shifting the focus from the langue level of LSPs to the parole level, making extensive (if not even exclusive) use of authentic samples of specialised discourse (i.e. corpora). With the development of IT tools, corpus analysis has been incorporated in terminography and led to "textual Terminology" (Bourigault/Slodzian 1999), which aims at reflecting the actual use of terminological units in authentic specialised contexts. It is exactly in textual Terminology that the study on short-period terminological evolution presented in this paper falls within.

\section{DIACHRONIC TERMINOLOGICAL VARIATION IN EU TEXTS}

The cue for the study presented here is to be found in Picton's article on shortperiod diachronic phenomena in specialised corpora (2011), where she investigates four linguistic clues affecting terminology that point at the evolution of knowledge in texts dealing with the domain of space technologies. The linguistic clues she suggests as indicators of knowledge evolution are: frequency, knowledge-rich contexts, (co)existence of term variants and syntactic dependency (Picton 2011: 139-141). The aim of this paper is to verify whether one of these clues, namely the (co)existence of term variants, can also be observed in other domains. In order to pursue such aim, a specific topic from the criminal law domain has been selected, i.e. victims of crime and their rights in criminal proceedings. Since this study falls within textual Terminology, for the purpose of studying terminological variation from a diachronic perspective the corpus described in the following subsection has been compiled.

\subsection{The victim-related EU corpus}

The central topic selected for this study is the area of criminal law of victims of crime. Since this topic has been tackled by legislators in a wide variety of legal systems and from different perspectives for diverse purposes (e.g. in the fields of criminology and victimology), to compile a corpus the research domain was further narrowed by collecting texts that have a single origin (they were all retrieved from the Eur-Lex ${ }^{1}$ website). The texts

1 http://eur-lex.europa.eu/en/index.htm 
were selected on the basis of their relevance to the central topic and cover a time span of fifteen years (1998-2012), which makes the corpus a 'short-diachronic corpus' (see Picton 2011: 138). Moreover, the study is bilingual in that it takes into account the EU varieties of English and Italian. The number of texts per language is 70, while the number of tokens and types for each subcorpus is shown in Table 1.

\begin{tabular}{|l|l|l|}
\cline { 2 - 3 } \multicolumn{1}{c|}{} & English subcorpus & Italian subcorpus \\
\hline tokens & 344,532 & 360,620 \\
\hline types & 9,088 & 12,760 \\
\hline
\end{tabular}

Table 1: Number of tokens and types in the English and Italian subcorpus

\subsection{Diachronic terminological phenomena in EU victim-related texts}

In order to describe diachronic terminological phenomena, it is firstly necessary to introduce the distinction elaborated by Rodolfo Sacco (1991, further developed by Gambaro and Sacco 1996) between genotypes and phenotypes, which proves useful for understanding the conceptual changes in legal notions over time. When considering a legal notion, its conceptual content can be split into a specific concept or phenotype, i.e. the empirical manifestation of the legal notion within a specific legal system, and a basic concept or genotype, i.e. a "superabstract notion" (Garzone 2000: 8) which is limited to the essential elements of the legal notion, regardless of the legal system it has been extracted from (Pasa 2007: 8). Bearing this distinction in mind, the conceptual changes that occur at the phenotype level without altering the connection with the genotype can be traced.

The diachronic phenomena concerning EU victim-related terminology are here analysed against Picton's typology of short-period diachronic phenomena (2011: 142148 ), taking into consideration novelty and obsolescence, implantation of terms and concepts and centrality. These three categories are here combined with the threefold classification proposed by Tartier (2003), which comprises stability, appearance and disappearance. By applying such classifications to the terminology extracted from the EU victim-centred corpus, the behavioural patterns of terminology can be classified into two main groups, i.e. stability and lack of stability.

\subsubsection{Stability}

In this paper, stability shall be understood as the consistent usage of terms in the short-period diachronic corpus analysed (mononymy). This phenomenon is the least frequent pattern in the terminology extracted from the analysed corpus. Although the terms extracted from the two subcorpora should designate the same legal reality, the terminology in different EU languages not always behaves in the same way, since it is possible to identify cases where univocal terms are used in one of the two languages under examination, while in the other non-univocal terms are used. 


\subsubsection{Univocal terms in both languages}

In Table 2, examples of terms that are univocal in both languages are provided. Such terms refer to the same concept (both at the phenotype and genotype level) and their usage is consistent in the EU corpus, leading to cases where mononymy is reflected in both English and Italian.

\begin{tabular}{|l|l|l|}
\hline English univocal term & Italian univocal term & Time span \\
\hline bystander & passante & $2001-2002$ \\
\hline mediator & mediatore & 2004 \\
\hline European protection order & ordine di protezione europeo & $2010-2012$ \\
\hline executing State & Stato di esecuzione & $2010-2011$ \\
\hline issuing State & Stato di emissione & $2010-2011$ \\
\hline person causing danger & persona che determina il pericolo & $2010-2011$ \\
\hline protected person & persona protetta & $2010-2011$ \\
\hline State of supervision & Stato di sorveglianza & $2010-2011$ \\
\hline
\end{tabular}

Table 2: Correspondence of univocal terms in the EU corpus

The stability observed by examining the examples listed in Table 2 can be explained in the light of Picton's classification. Actually, the examples provided share a common trait: their time span is very short. The term mediator is found in one document only ${ }^{2}$ and can thus be said to be like a meteor in the sky of EU victim-related documents. The same can be said for the term bystander, which is used in one main document ${ }^{3}$ and mentioned once in an EESC opinion. ${ }^{4}$ Although the remaining cases listed in Table 2 may seem similar to these two examples by reason of their short time span (2010-2011 or 2012), there is a difference between the two groups which resides in the degree of centrality of the concepts designated by such terms to the main topic of both the whole corpus and the specific documents.

Imagining the degrees of centrality of a certain concept to a specific topic as a series of concentric circles, the concept designated by the term bystander (meaning a person that is accidentally hurt during the commission of a crime) is likely to be in the most peripheral circle. This is so because the underlying concept plays a marginal role in the development of victim-related legislation, since EU provisions concern exclusively direct and indirect victims (the persons towards whom the offence is directed and their dependants and other

2 Green Paper on the approximation, mutual recognition and enforcement of criminal sanctions in the European Union, $\operatorname{COM}(2004) 334$ final.

3 Green Paper Compensation to crime victims, $\operatorname{COM}(2001) 536$ final.

4 Opinion of the Economic and Social Committee on the "Green Paper on compensation to crime victims", OJ C 125/31, 27 May 2002. 
relatives). The term mediator, on the other hand, is in a more central position, given that mediation between the victim and the offender is considered as an alternative solution to court proceedings in which the victim is directly involved. The other examples in Table 2 are also more central: they all concern the European Protection Order, which is a decision whereby appropriate measures are taken to protect a protected person (a victim). Given that this decision corresponds to a concept elaborated within the EU and that a Directive $^{5}$ was adopted in 2011 to establish it, the development of the relevant terminology followed the development of the conceptual framework. Therefore, new terms were coined to suit the designatory needs of EU institutions. Since the Directive at issue is very recent and Member States have time to comply with it until 2015, it is not possible to foresee whether these terms, which are a high-priority issue in the current victim-related debate, will be subject to further terminological evolution or will maintain a high degree of stability, at least in the languages analysed in this paper.

\subsubsection{Univocal terms in one language only}

In the corpus there are also cases where a univocal term is used in only one of the two languages under examination, while in the other a certain degree of variation can be observed. Examples of this phenomenon are shown in Tables 3 and 4.

\begin{tabular}{|l|l|l|l|}
\hline English univocal term & Time span & Italian non-univocal term & Time span \\
\hline child-friendly justice & 2011 & $\begin{array}{l}\text { giustizia a misura di minore } \\
\text { giustizia adattata ai bambini }\end{array}$ & $\begin{array}{l}2011 \\
2011\end{array}$ \\
\hline \multirow{2}{*}{ secondary victimisation } & \multirow{2}{*}{$2001-2012$} & $\begin{array}{l}\text { vittimizzazione secondaria } \\
\text { ulteriore vittimizzazione } \\
\text { pregiudizio secondario }\end{array}$ & $\begin{array}{l}2002,2009-2012 \\
2010-2012 \\
2001\end{array}$ \\
\hline \multirow{2}{*}{ witness } & \multirow{2}{*}{$2002-2012$} & $\begin{array}{l}\text { testimone } \\
\text { teste }\end{array}$ & $\begin{array}{l}2002-2012 \\
2003-2009\end{array}$ \\
\hline
\end{tabular}

Table 3: Lack of correspondence in the usage of English univocal and Italian non-univocal terms in the EU corpus

\begin{tabular}{|l|l|l|l|}
\hline English non-univocal term & Time span & Italian univocal term & Time span \\
\hline assisting authority & $2002-2004$ & autorità di assistenza & $2002-2009$ \\
Assisting Authority & 2009 & & \\
\hline deciding authority & $2002-2004$ & autorità di decisione & $2002-2009$ \\
Deciding Authority & 2009 & & \\
\hline
\end{tabular}

Table 4: Lack of correspondence in the usage of English non-univocal and Italian univocal terms in the EU corpus

5 Directive 2011/99/EU of the European Parliament and of the Council of 13 December 2011 on the European protection order, OJ L 338/2, 21 December 2011. 
The list of examples provided above is not meant to be comprehensive, but it attempts to give a brief overview of the various behavioural patterns of the EU terminology in different languages. For instance, Table 3 shows that in English it is possible to identify terms that are used consistently, while the same EU concept is designated by a set of variants in the Italian subcorpus. The same can also be said for the stability of certain Italian terms as compared to English, although the English examples are characterised by graphical variation, while the Italian examples fall within "paradigmatic variation" (Daille 2005: 185). Notwithstanding the differences in the types of variation, it is worth noticing that in some cases the extracted terms behave in the same way (stability in both languages), while in other they behave differently (stability vs. variation), although the texts from which they are extracted are to be considered as equally authentic.

\subsubsection{Lack of stability}

The second behavioural pattern identified in the EU corpus is lack of stability or terminological variation. From a synchronic perspective, terminological variation can be understood as the existence of several terms designating the same concept. If the diachronic dimension is considered, terminological variation can be viewed as a more complex phenomenon which encompasses appearance, disappearance and co-existence of terms. However, it should not be overlooked that, since the approach adopted in this study takes the standpoint of textual Terminology, phenomena such as term appearance and disappearance are to be considered in their relativity to the object of study, i.e. the corpus under examination. In other words, the cases of appearance or disappearance are not absolute nor general, but rather relative to the texts analysed.

In order to illustrate the different behaviour of English and Italian terms, the Italian concept of SECONDARY VICTIMISATION seen in Table 3 is taken as example. While the English equivalent secondary victimisation is stable, the behaviour of Italian terms can be summarised as shown in Table 5 .

\begin{tabular}{|l|l|l|l|l|l|l|l|l|}
\hline Term sime span & $\begin{array}{c}\text { 1998- } \\
\text { 2000 }\end{array}$ & 2001 & 2002 & $\begin{array}{c}2003- \\
2008\end{array}$ & 2009 & 2010 & 2011 & 2012 \\
\hline vittimizzazione secondaria & & & & & & & & \\
\hline ulteriore vittimizzazione & & & & & & & & \\
\hline pregiudizio secondario & & & & & & & & \\
\hline
\end{tabular}

Table 5: Lack of stability of Italian terms designating SECONDARY VICTIMISATION

Table 5 shows that the Italian terms designating SECONDARY VICTIMISATION have evolved. When the concept was first introduced in the discussion on victims of crime at the EU level in 2001, the term pregiudizio secondario was used. The following year the term was replaced by vittimizzazione secondaria, which has also been the 
most frequent term to refer to this concept ever since, and in 2010 ulteriore vittimizzazione was first used. This example shows all the three possible manifestations of the lack of stability in the EU corpus: all three terms appear at a certain point in time, although only one disappears (pregiudizio secondario) and the remaining two coexist in the corpus for a certain period of time (2010-2012).

Moreover, non-univocal terms can also be used in both languages to refer to the same EU concept. This is the case of the terms referring to the concept of MEDIATION IN CRIMINAL CASES presented in Tables 6 and 7.

\begin{tabular}{|c|c|c|c|c|c|c|c|c|c|c|}
\hline Term & $\begin{array}{r}1998- \\
2000\end{array}$ & 2001 & 2002 & 2003 & 2004 & $\begin{array}{l}2005- \\
2008\end{array}$ & 2009 & 2010 & 2011 & 2012 \\
\hline $\begin{array}{l}\text { mediation in criminal } \\
\text { cases }\end{array}$ & & & & & & & & & & \\
\hline $\begin{array}{l}\text { mediation in criminal } \\
\text { proceedings }\end{array}$ & & & & & & & & & & \\
\hline $\begin{array}{l}\text { mediation between } \\
\text { the offender and his } \\
\text { victim }\end{array}$ & & & & & & & & & & \\
\hline $\begin{array}{l}\text { mediation between } \\
\text { victims and offenders }\end{array}$ & & & & & & & & & & \\
\hline $\begin{array}{l}\text { penal mediation in } \\
\text { the course of criminal } \\
\text { proceedings }\end{array}$ & & & & & & & & & & \\
\hline penal mediation & & & & & & & & & & \\
\hline $\begin{array}{l}\text { victim-offender } \\
\text { mediation }\end{array}$ & & & & & & & & & & \\
\hline $\begin{array}{l}\text { mediation in penal } \\
\text { matters }\end{array}$ & & & & & & & & & & \\
\hline
\end{tabular}

Table 6: English terms designating MEDIATION IN CRIMINAL CASES 


\begin{tabular}{|c|c|c|c|c|c|c|c|c|c|c|}
\hline Term Time span & $\begin{array}{c}1998- \\
2000\end{array}$ & 2001 & 2002 & 2003 & 2004 & $\begin{array}{c}2005- \\
2008\end{array}$ & 2009 & 2010 & 2011 & 2012 \\
\hline \multicolumn{11}{|l|}{ mediazione penale } \\
\hline \multicolumn{11}{|l|}{$\begin{array}{l}\text { mediazione } \\
\text { nell'ambito dei } \\
\text { procedimenti penali }\end{array}$} \\
\hline \multicolumn{11}{|l|}{$\begin{array}{l}\text { mediazione nelle } \\
\text { cause penali }\end{array}$} \\
\hline \multicolumn{11}{|l|}{$\begin{array}{l}\text { mediazione tra autore } \\
\text { e vittima del reato }\end{array}$} \\
\hline \multicolumn{11}{|l|}{$\begin{array}{l}\text { mediazione tra la } \\
\text { vittima e l'autore del } \\
\text { reato nell'ambito dei } \\
\text { procedimenti penali }\end{array}$} \\
\hline \multicolumn{11}{|l|}{$\begin{array}{l}\text { mediazione tra vittima } \\
\text { e autore del reato nel } \\
\text { procedimento penale }\end{array}$} \\
\hline \multicolumn{11}{|l|}{$\begin{array}{l}\text { mediazione vittima- } \\
\text { reo }\end{array}$} \\
\hline $\begin{array}{l}\text { mediazione vittima- } \\
\text { autore del reato }\end{array}$ & & & & & & & & & & \\
\hline
\end{tabular}

Table 7: Italian terms designating MEDIATION IN CRIMINAL CASES

Also in this example phenomena of appearance, disappearance and co-existence can be identified. However, here the short-diachronic period taken into account (1998-2012) can be further subdivided into two shorter periods, corresponding to the periods in which mediation was dealt with - or at least mentioned - at the EU level in documents related to the topic of victims of crime. It can thus be said that the concept had two concentration peaks: in the first period the concept and the relevant terms appeared, representing a case of novelty in Picton's words, while in the second some terms disappeared and some others appeared, denoting the obsolescence of the former but the implantation of the underlying concept and its centrality to the main topic.

All the examples provided so far concern concepts that coincide at the genotype and phenotype level. However, a change in the terminology used can also be an indication of a change at the conceptual level. An example of this phenomenon is provided in Table 8. 


\begin{tabular}{|l|l|l|l|l|l|l|l|l|l|}
\hline Time span & $\begin{array}{c}\text { 1998- } \\
2001\end{array}$ & 2002 & 2003 & 2004 & $\begin{array}{c}\text { 2005- } \\
2008\end{array}$ & 2009 & 2010 & 2011 & 2012 \\
\hline $\begin{array}{l}\text { particularly } \\
\text { vulnerable victim }\end{array}$ & & & & & & & & & \\
\hline vulnerable victim & & & & & & & & & \\
\hline $\begin{array}{l}\text { particularly } \\
\text { vulnerable person }\end{array}$ & & & & & & & & & \\
\hline $\begin{array}{l}\text { victim with specific } \\
\text { protection needs }\end{array}$ & & & & & & & & & \\
\hline
\end{tabular}

Table 8: English terms designating VICTIM WITH SPECIFIC PROTECTION NEEDS

In Table 8, the English terms designating the concept of VICTIM WITH SPECIFIC PROTECTION NEEDS are reported. The first term to refer to this concept dates back to 2002, but the concept itself drifted in victim-related debate at the EU level earlier, namely when "victims who are particularly vulnerable" were mentioned in 2000 in the Initiative of the Portuguese Republic $^{6}$ and in Framework Decision 2001/220/JHA. ${ }^{7}$ Following the life cycle of English terms, it can be noticed that the terminologisation occurred after the concept was introduced in the EU legal system and, although at the beginning only one term was used (particularly vulnerable victim), later two variants and a new term appeared. The appearance of these alternative designations does not always point at cases of perfect synonymy. The inclusion of the genotype/phenotype distinction may help understand what is meant here. When the concept at issue was first introduced in the EU legal system, no definition was provided. Although the genotype can be inferred from the term itself, i.e. a victim who is more vulnerable than victims in general, the information necessary to depict the concept at the phenotype level is not available in a "classical" Aristotelian definition, but is rather scattered in documents both prior and subsequent to the first occurrence of the terminologised unit. Actually, from such documents it emerges that certain subcategories of victims could be assimilated to this group on the basis of different criteria (e.g. sex, age) which characterise the phenotype level of the concept. Therefore, certain categories, such as child victims and women victims of domestic violence, are considered as particularly vulnerable victims a priori. The two following terms in Table 8 are respectively a short form of particularly vulnerable victim and thus its synonym and a paradigmatic variant. Although the presence of "person" instead of "victim" may suggest a broader category and therefore a shift in the phenotype, the contexts in which the variant occurs makes it possible to establish a high degree of synonymy, as in the following example (emphasis added):

6 Initiative of the Portuguese Republic with a view to adopting a Council Framework Decision on the standing of victims in criminal procedure, OJ C 232/61, 17 August 2001.

7 Council Framework Decision of 15 March 2001 on the standing of victims in criminal proceedings (2001/220/JHA), OJ L 82/1, 22 March 2001. 
When the offence is committed in certain circumstances, for example against a particularly vulnerable victim, the penalty should be more severe. In the context of this Directive, particularly vulnerable persons should include at least all children. Other factors that could be taken into account when assessing the vulnerability of a victim include, for example, gender, pregnancy, state of health and disability. ${ }^{8}$

However, while for the first three terms listed in Table 8 a correspondence at both the genotype and phenotype level can be established, the same cannot be said for victims with specific protection needs introduced by Directive 2012/29/EU ${ }^{9}$ at the end of 2012. Applying the genotype/phenotype distinction, a genotype that is common to all the above-mentioned terms can be outlined: victims who are more vulnerable than victims in general. However, even if correspondence at the genotype level can be established, there are undeniable differences in the phenotypes concerned. As noted earlier, when particularly vulnerable victims entered the discussion on victim-related issues, closed subcategories of victims were determined on the basis of pre-established criteria. Later a conceptual shift was produced towards the more fuzzy-edged, loosely conceived notion of victims who cannot be identified a priori: their degree of vulnerability needs to be established through an individual assessment and only then their specific protection needs can be determined and specific measures adopted. The conceptual difference between the two phenotypes is significant, let us just think of the need to institute an individual assessment procedure in order to identify victims' specific protection needs. The elaboration of the concept has thus been followed by the introduction of a new term to refer to it.

Peering at what has been discussed so far through Picton's lenses and concentrating only on the diachronic outline in Table 8, the introduction of new terms at different points in time may be assimilated to Picton's category of novelty and obsolescence and the repeated usage of the term particularly vulnerable victim in the two sub-periods (2002-2004 and 20092012) can be interpreted as the implantation of the underlying concept due to the centrality of the topic. However, a closer look at the contexts in which the term occurs in more recent documents (dated 2011-2012) and the introduction of the new term victim with specific protection needs allow to observe that, regardless of the high frequency of particularly vulnerable victim, it is giving way to the other term, since the phenotype elaborated more recently is prevailing on the other. This means that, although on the basis of the available data it would be possible to infer that the term with the longest life cycle and the highest number of occurrences is also the most "mature" term and the concept it designates is also central in the victim-related discussion, the presence of alternative, albeit less frequent terms which point at different phenotypes indicates that the topic concerned is undergoing a conceptual shift.

8 Directive 2011/36/EU of the European Parliament and of the Council of 5 April 2011 on preventing and combating trafficking in human beings and protecting its victims, and replacing Council Framework Decision 2002/629/JHA, OJ L 101/1, 15 April 2011.

9 Directive 2012/29/EU of the European Parliament and of the Council of 25 October 2012 establishing minimum standards on the rights, support and protection of victims of crime, and replacing Council Framework Decision 2001/220/JHA, OJ L 315/57, 14 November 2012. 


\section{CONCLUSION}

In this paper the phenomenon of terminological variation in victim-centred EU texts was analysed from a diachronic perspective. The study of the terminology extracted from a short-period (1998-2012) corpus of English and Italian texts made it possible to prove that the terms referring to a common supranational legal system follow two main behavioural patterns. The first is here called "stability" following Tartier (2003) and manifests itself in two different ways: on the one hand, the consistent usage of a univocal term in both the languages analysed and, on the other, the consistent usage of a univocal term in one language only, while in the other language a certain degree of variation can be identified. The second pattern, i.e. "lack of stability", represents the other side of the coin: it actually consists in the terminological variation due to the appearance, disappearance and co-existence of a set of terms in one or two languages to refer to a single concept during the short period of time at issue. As far as the second pattern is concerned, different examples made it possible to illustrate how terminology evolves. By adopting Sacco's (1991) genotype/phenotype distinction, two cases were spotted. In the first one, the phenotype and genotype coincide even if different terms are used to designate the same concept, without entailing a conceptual change. In the second case, although the genotype remains unaltered, the phenotype changes in the course of time giving rise to a conceptual evolution in the knowledge field and such change is accompanied by terminological variation. The cases of stability and lack of stability identified in the corpus were also analysed against Picton's (2011) classification of evolution phenomena, in order to verify if the categories proposed by her could also explain the phenomena depicted in EU legal texts.

\section{References}

BOURIGAULT, Didier/Monique SLODZIAN (1999) "Pour une terminologie textuelle." Terminologies Nouvelles 19, 29-32.

CABRÉ, Maria Teresa (1999) Terminology: Theory, Methods and Applications. Amsterdam/Philadelphia: John Benjamins.

CABRÉ, Maria Teresa (2000) "Elements for a theory of terminology: Towards an alternative paradigm." Terminology 6/1, 35-57.

CABRÉ, Maria Teresa (2003) "Theories of Terminology. Their description, prescription and explanation.” Terminology 9/2, 163-199.

CONDAMINES, Anne/Josette REBEYROLLE (1997) "Point de vue en langue spécialisée." Meta: journal des traducteurs 42/1, 174-184.

DAILLE, Béatrice (2005) "Variations and Application-oriented Terminology Engineering." Terminology 11/1, 181-197.

ERIKSEN, Lars H. (2002) "Die Polysemie in der Allgemeinsprache und in der juristischen Fachsprache Oder: Zur Terminologie der 'Sache' im Deutschen." Hermes, Journal of Linguistics 28, 211-222.

FERRARI, Laura (2002) “ ¿Un caso de polisemia en el discurso jurídico?” Terminology $8 / 2,221-244$. 
FREIXA, Judit (2002) La variació terminològica. Anàlisi de la variació denominativa en textos de diferent grau d'especialització de l'àrea de medi ambient. Filologia Catalana. Barcelona: Universitat de Barcelona.

GAMBARO, Antonio/Rodolfo SACCO (1996) Sistemi giuridici comparati. Torino: UTET.

GARZONE, Giuliana (2000) "Legal Translation and Functionalist Approaches: a Contradiction in Terms?" In: Actes du Colloque International "La traduction juridique. Histoire, théorie(s) et pratique”. (Geneva, 17-19 February 2000). Geneva: École de Traduction et d'Interprétation, University of Geneva, 395-414.

GAUDIN, François (1993) Pour une socioterminologie: des problèmes pratiques aux pratiques institutionnelles. Rouen: Université de Rouen.

GAUDIN, François (2003) Socioterminologie: une approche sociolinguistique de la terminologie. Brussels: Éditions Duculot.

HAJIČOVA Eva/Anka KOTEŠOVCOVÁ/Jiří MÍROVSKÝ (eds) (2003) Proceedings of the 17th International Congress of Linguists (CIL17) (Prague, 24-29 June 2003). Prague: Matfyzpress, MFF UK (CD-ROM).

HEINE, Carmen/Jan ENGBERG (eds) (2010) Reconceptualizing LSP. Online proceedings of the XVII European LSP Symposium. (Aarhus, 17-21 August 2009). Aarhus: Online.

IBEKWE-SANJUAN, Fidelia (1998) "Terminological variation, a means of identifying research topics from texts." In: C. Boitet/P. Whitelock (eds), Proceedings of the 17th International Conference on Computational Linguistics (COLING-ACL '98). (Montreal, 10-14 August 1998). Canada: Morgan Kaufmann Publishers, 564-570.

KERREMANS, Koen (2010) "A Comparative Study of Terminological Variation in Specialised Translation.” In: C. Heine/J. Engberg (eds), 1-14.

PASA, Barbara (2007) "Old terms for new concepts in consumer contracts?" Jean Monnet Working Paper 9/07. 8 May 2012. http://centers.law.nyu.edu/jeanmonnet/ papers/07/070901.pdf.

PICTON, Aurélie (2011) "Picturing short-period diachronic phenomena in specialised corpora: A textual terminology description of the dynamics of knowledge in space technologies." Terminology 17/1, 134-156.

SACCO, Rodolfo (1991) La comparaison juridique au service de la connaissance du droit. Paris: Economica.

TARTIER, Annie (2003) “A Method for Observing Terminological Evolution.” In: G. Angelova/K. Bontcheva/R. Mitkov/N. Nikolov (eds), Proceedings of the Conference "Recent Advances in Natural Language Processing" (RANLP '03). Amsterdam/Philadelphia: John Benjamins, 467-471.

TEMMERMAN, Rita (2000) Towards New Ways of Terminology Description: the Sociocognitive Approach. Amsterdam/Philadelphia: John Benjamins.

TEMMERMAN, Rita/Koen KERREMANS (2003) "Termontography: Ontology Building and the Sociocognitive Approach to Terminology Description." In E. Hajičová/A. Kotešovcová/J. Mírovský (eds). 
WÜSTER, Eugen (1979) Einführung in die Allgemeine Terminologielehre und Terminologische Lexikographie. Wien/New York: Springer.

ZAWADA, Britta E./Piet SWANEPOEL (1994) "On the empirical adequacy of terminological concept theories: The case for prototype theory." Terminology $1 / 2$, 253-275.

\section{Abstract \\ SHORT-PERIOD EVOLUTION IN EU LEGAL TEXTS: OLD AND NEW TERMS, OLD AND NEW CONCEPTS}

Due to the ever-changing legal landscape of the European Union, the terminology used in EU documents is subject to constant formal and conceptual evolution. In this paper, a bilingual (Italian and English) corpus of equally authentic EU legal texts covering a time span of fifteen years (1998-2012) and concerning the legal area of victims of crime is analysed from a diachronic perspective. The aim is to discuss the terminological changes observed in the corpus in the light of the classification of evolution phenomena proposed by Tartier (2003) and Picton (2011). In order to examine both formal and conceptual terminological evolution, the distinction between genotypes and phenotypes introduced by Sacco (1991) is applied to the terms identified in the corpus and the underlying concepts. The analysis of the EU corpus shows that the three categories proposed by Tartier (appearance, disappearance and stability) and the first three (novelty and obsolescence, implantation of terms and concepts, and centrality) of the four categories proposed by Picton for the terminology of space technologies also apply to the terms of the examined legal area.

Keywords: legal terminology, terminological variation, diachronic evolution, textual terminology, EU terminology.

\section{Povzetek}

\section{KRATKOROČNI RAZVOJ V PRAVNIH BESEDILIH EVROPSKE UNIJE: STARI IN NOVI TERMINI, STARI IN NOVI POJMI}

Zaradi nenehno spreminjajoče se pravne situacije v Evropski uniji doživlja terminologija v dokumentih EU stalen razvoj na formalni in pojmovni ravni. Članek z diahronega vidika analizira dvojezični (italijanski in angleški) korpus, sestavljen iz enakovrednih avtentičnih pravnih besedil EU, ki so nastala $\mathrm{v}$ obdobju zadnjih petnajstih let (od 1998 do 2012), in obravnava področje prava, povezanega z žrtvami kaznivih dejanj. Avtorica skuša razložiti terminološke spremembe, ki jih je zasledila v preučevanem korpusu, in sicer na podlagi klasifikacije evolucijskega fenomena, ki sta jo vpeljali A. Tartier (2003) in A. Picton (2011). Da bi preučila tako formalno kot konceptualno evolucijo terminologije, je avtorica pri terminih v izbranem korpusu ter z njimi povezanih pojmih uporabila metodo razlikovanja med genotipi in fenotipi, ki jo je povzela 
po Saccu (1991). Analiza korpusa besedil EU je pokazala, da tri kategorije, ki jih je predlagala Tartierova (nastanek, izginotje in nespremenljivost), ter prve tri od štirih kategorij, ki jih je za terminologijo vesoljske tehnologije predlagala Pictonova (novost in zastarelost, implantacija terminov in pojmov ter centralnost), veljajo tudi za termine preučevanega pravnega področja.

Ključne besede: pravna terminologija, terminološke spremembe, diahroni razvoj, besedilna terminologija, terminologija EU. 